\title{
Evaluation of Married Haemoglobinopathic Carrier Couples for Prevention of Haemoglobinopathic Births
}

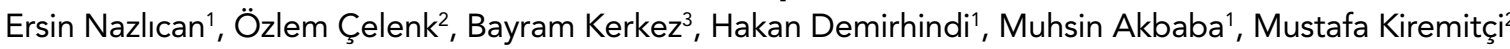 \\ ${ }^{1}$ Department of Public Health, Çukurova University Faculty of Medicine, Adana, Turkey \\ ${ }^{2}$ Projects Departmant, Provincial Health Directorate, Hatay, Turkey \\ ${ }^{3}$ Vice Chancellor, Antakya State Hospital, Hatay, Turkey
}

\begin{abstract}
Background: Abnormal haemoglobins $(\mathrm{Hb})$ and thalassaemias are some of the most frequently observed hereditary disorders in the world, but especially in the Mediterranean region where Turkey is located. Hatay province is one of the largest provinces in the region, suggested as a target area to be selected for preventive programs after studies by three Turkish universities, i.e. Çukurova, Akdeniz and Hacettepe Universities in Turkey.

Aims: The aim of this study was to determine demographic and family characteristics of all haemoglobinopathy carrier married couples registered in the Hatay Provincial Health Directorate registry and to educate the target population about pregnancy, births, prenatal diagnosis and genetic counselling with the particularly emphasised scope of eliminating all haemoglobinopathic births.
\end{abstract}

Study design: Descriptive cross-sectional and intervention study.

Methods: 1065 couples both being haemoglobinopathic carriers, registered in the Hatay Provincial Health Directorate registry were investigated for sociodemographic characteristics, obstetrical status and especially for a present pregnancy, the presence of any haemoglobinopathic patients or carrier children in the family.

Results: Among women with a history of pregnancy, $47.3 \%$ reported that they had never had any prenatal testing, while $33.1 \%$ had got received testing in each of their pregnancies. The most frequent reason for not having the test was declared as unawareness of the test (66.0\%), followed by economic insufficiencies (17.1\%), destiny/religious reasons $(9.1 \%)$ and family interference $(7.8 \%)$. After a series of descriptive analyses, the results of the final binary logistic regression model constructed to find out the risk factors significantly affecting the presence of a sick child in the family were grouped as risk increasing factors like age $(95 \% \mathrm{Cl}$ between 1.002 and 1.122$)$, marriage before $1994(95 \% \mathrm{Cl}=1.081-4.161)$, and risk decreasing factors like family willingness for screening $(95 \% \mathrm{Cl}=0.167-0.854)$, rate of prenatal testing $(95 \% \mathrm{Cl}=0.147-0.414)$, age at first pregnancy $(95 \% \mathrm{Cl}=0.469-0.882)$; while the frequency of births was found to have no significant effect ( $p>0.05)$.

Conclusion: Besides all legal regulations and applications, time is still needed for real success against such a diffuse and congenitally transferred disease. The education of the target populations appears to be crucial. Official applications should be forced based upon present or future laws.

Key Words: Haemoglobinopathies, prenatal diagnosis, Mediterranean, Turkey, birth

Received: 05.03.2013

Accepted: 13.06.2013

Available Online Date: 27.09.2013

\section{Introduction}

Abnormal haemoglobins $(\mathrm{Hb})$ and thalassaemias are some of the most frequently observed hereditary disorders in the world, but especially in the Mediterranean region where Turkey is also located, with clinical profiles that range from asymptomatic to lethal (1-3). The World Health Organisation $(\mathrm{WHO})$ reports that the frequency of thalassaemias and abnormal $\mathrm{Hb}$ carriers is $5.1 \%$ with nearly 226 million carriers worldwide (4-6). Haemoglobin $\mathrm{S}(\mathrm{HbS})$ is the most frequently observed haemoglobin disorder in Turkey (7). Beta $(\beta)$-thalassaemia is one of the leading haemoglobinopathy types in Turkey, as it is worldwide, being observed especially in the Mediterranean zone comprising Mediterranean countries from north and western Africa to Middle East and southeastern Asia $(8,9)$. Global migration in the modern period has led to a continual spread of these anomalies to all regions of the World, with the result that they are rapidly becoming more common in industrialised regions of Northern and Central Europe as well (10). Nearly $4.5 \%$ of the world population has been reported to carry a $\beta$-thalassaemia mutation (11). More frequent $\beta$-thalassaemic child births than expected derive from frequent consanguinity in marriages and high birth rates in Turkey (12).

The expected number of carriers is $1,400,000$ and the number of patients is approximately 5,000 in Turkey. In 2006, as reported by the Ministry of Health and the Turkish National Haemoglobinopathy Council, the results of screening studies comprising 377,339 healthy subjects from 16 different cities of Turkey revealed the mean frequency of $\beta$-thalassaemia trait to be $4.3 \%$. The highest prevalence of the $\beta$-thalassaemia trait (13.1\%) was observed in Antalya region and that of the $\mathrm{HbS}$ trait $(10 \%)$ in Çukurova region, both regions located at the Mediterranean coast of Turkey (13). The carrier rate of sickle cell anaemia (SCA) was found to be $10 \%$ in the region of Çukurova, $8 \%$ in Hatay and $6.1 \%$ in Mersin, again all Mediter- 
ranean cities of Turkey (14). The incidence of $\alpha$-thalassaemia in Turkey was reported to be between $3.3 \%$ and $8 \%$, that of $\beta$-thalassaemia between $0.7 \%$ and $13.5 \%$, that of $\mathrm{HbS}$ between $0.5 \%$ and $47 \%$ and that of Haemoglobin $\mathrm{D}(\mathrm{HbD})$ to be $0.3 \%(7,15,16)$.

Since there is no definitive cure for these hereditary diseases, WHO has suggested a control program comprising enlightenment of the public, screening for carriers, prenatal diagnosis and genetic counselling, including the screening of other members of the family where haemoglobinopathy is encountered in any of the members; this could result in the prevention of the birth of an affected child $(9,17,18)$. Italy, Greece, Canada, the United Kingdom and South Cyprus started the program in the 1970s and achieved success (17, $19,20)$, which was expressed with only five thalassaemic babies born between 1991 and 2001 and no thalassaemic babies born in the latter since 2001, as a striking example (21). The year 1994 is crucial for Turkey due to the commencement of the law "Fight against Hereditary Diseases" on Dec 28 1993, constituting the basis of the establishment of centres providing pre-marital $\mathrm{Hb}$ electrophoresis blood tests, which was declared to be obligatory by the Hatay Provincial Health Directorate in 1994, although the obligation was being discussed by the legal professionals $(22,23)$. This region was suggested as a target area to be selected for preventive programs after studies by three Turkish universities, i.e. Çukurova, Akdeniz and Hacettepe Universities (7).

We aimed to determine demographic and family characteristics of all haemoglobinopathy carrier married couples registered in the Hatay Provincial Health Directorate registry, and to educate the target population about pregnancy and births, prenatal diagnosis and genetic counselling with the scope of eliminating all haemoglobinopathic births.

\section{Material and Methods}

This cross-sectional and interventional study was performed between March 2011 and March 2012 in Hatay province of Turkey comprising the central area and 12 districts of the province, including villages. Hatay Provincial Health Directorate registry revealed the presence of 1072 couples with both partners being haemoglobinopathic carriers, with a resulting study population of 2144 individuals; among them, 1065 (99.3\%) couples gave consent to actively participate in the study after being informed. A total of 29 (2.7\%) couples were at the pre-wedding stage, either single or engaged, but they were coded as "husbands" or "wives" according to their gender throughout the study. Two separate mobile teams, each consisting of a social worker and four nurses, were educated by a public health specialist medical doctor, all among the staff of Hatay Provincial Health Directorate about haemoglobinopathy diagnosis and the questionnaires to be used. The mobile teams visited all carrier couples at their residential addresses regardless of the distance. After giving informed consent, the couples were applied a questionnaire by face-to-face interviews to investigate the sociodemographic characteristics, obstetric status of the female partners and especially for a present pregnancy, the presence of any haemoglobinopathic patients or carrier children in the family. This constituted the descriptive part of the study. The second step, which was partly interventional, consisted of the education of the carrier couples about congenital blood diseases, prenatal diagnosis, genetic counselling and pregnancy. The pregnant women were investigated in more detail with additional questions and they were registered in the registry. The couples were referred to university hospital in cases of the absence of a prenatal haemoglobinopathy test and the results were followed for registry. If the test result revealed a haemoglobinopathic foetus, the family was informed and when the family preferred therapeutic abortus they were guided in cooperation with obstetricians. The female participants who were at a stage of pregnancy that was too late for prenatal diagnosis or who refused the test were closely followed for the final outcome of the pregnancy.

When the couples reported that their decision to marry was not affected by the results of screening tests, we did not insist on scrutinising this decision and the factors underlying this decision for ethical reasons. This was declared as the limitation of the study.

\section{Statistical analysis}

All data were digitalised and statistically analysed with EpiInfo 6.0 and SPSS 11.5 computer softwares. $\chi^{2}$ test, Student's ttest, binary logistic regression analyses were performed where appropriate. Statistical significance was accepted as $p<0.05$.

\section{Results}

Among the 1065 participant couples, husbands (mean age of 38.9 \pm 9.4 ) were significantly older than the wives (mean age of $33.0 \pm 9.4)(t=20.5, d f=1064, p<0.001)$. The majority of couples were married between the ages of 18 and 21 (43.7\%), followed by those younger than 18 years of age group (24.5\%).

Nearly $75 \%$ of couples reported to be at a middle income level, with a small per cent (10.0\%) not being covered by any social security assurance.

The wives were found to be less educated than the husbands with the most significant difference at the illiterate and literate with no school diploma group ( 3 times) $\left(\chi^{2}=41.2, d f=5, p<0.001\right)$.

The kinship of the first and second grade was reported by $280(26.3 \%)$ and $106(10.0 \%)$ couples, respectively.

A total of $860(83.0 \%)$ couples were married after 1994; among them, 817 (95.0\%) performed a pre-marital test (mostly as $98.9 \%$ due to legal obligation and $1.1 \%$ due to having a carrier in the family) compared to only 9 (5.1\%) couples married before 1994 with 3 (33.3\%) due to having a haemoglobinopathic child and the remaining 6 (66.7\%) due to having a carrier member in the family. This dramatic increase was statistically significant $\left(\chi^{2}=724.9, \mathrm{df}=1, \mathrm{p}<0.001\right)$.

Haemoglobinopathy types were observed in different combinations among the first and the second individual of the couple, mostly in carrier form (62.2\%) as $\mathrm{HbAS}+\mathrm{HbAS}$, followed by $\mathrm{HbA} \beta+\mathrm{HbA} \beta$ (17.1\%) and $\mathrm{HbAS}+\mathrm{HbA} \beta$ (9.8\%). It was worth emphasising the presence of sick couples as: one couple with $\mathrm{Hb} B+\mathrm{HbA} \beta$, one with $\mathrm{HbSS}+\mathrm{HbA} \beta$ and one with $\mathrm{HbB}+\mathrm{Hb} A \mathrm{~S}$ combination. No kinship was present in these last three couples. 
Three $(0.3 \%)$ of the $13(1.2 \%)$ couples who resigned to marrying after having been informed about their carrier state, and $21(2.0 \%)$ of $237(22.3 \%)$ couples whose decision to marry was not affected by the results of prenatal testing reported not having any information about haemoglobinopathies. When the couples were diagnosed as haemoglobinopathic, some families (either the family of the bride or that of the groom, or both) requested the screening of other members in their family for haemoglobinopathies. This willingness in the family for screening was observed in at least one of the families (7.9\%), or in both $(7.6 \%)$, in contrast to none $(84.5 \%)$ of the families.

The registry revealed a pregnancy frequency between 1 and 9 with a mean of $2.7 \pm 1.4$ (median=2), while $217(20.4 \%)$ of the wives had never been pregnant. Among women with history of pregnancy, $47.3 \%$ reported that they had never received any prenatal testing, while $33.1 \%$ had undergone this in every pregnancy of theirs. Hence, $19.6 \%$ of women had undertaken a prenatal test in some of their pregnancies. The most frequent reason for not having the test was declared as unawareness of the test (66.0\%), followed by economic insufficiencies (17.1\%), destiny/religious reasons (9.1\%) and family interference (7.8\%). Some of the women, who had been tested only in the first pregnancy but not in the following ones, explained this mostly by economic reasons (33.3\%), but $8.8 \%$ had a belief that this disease could be observed only at the first child.

Among the pregnant women carrying a haemoglobinopathic foetus, as revealed by prenatal testing, $91.6 \%$ preferred medical abortus, another $2.6 \%$ preferred medical abortus while being opposed by their families, and $5.8 \%$ voluntarily denied abortus and decided to give birth to this child.

Among 144 women determined to be pregnant during the study, 3 were not guided to prenatal testing as they were found to be $\alpha$-thalassaemic, another 4 as they had spontaneous abortus and 18 as they were at a stage of pregnancy older than 16 weeks (24). Haemoglobin electrophoresis test performed to these 18 children at sixth month postpartum revealed 2 healthy, 11 carrier and 5 haemoglobinopathic children. Prenatal test results of the remaining 119 of 144 pregnant women revealed 27 healthy, 73 carrier and 19 haemoglobinopathic children. The latter were suggested medical abortus at the educational and counselling part of the project. However, while 17 confirmed the operation, two preferred to let their pregnancy end naturally, even though they were sufficiently informed about blood diseases. Hence, the sum of sick children births reached 7 for the whole project (Table 1).

It was found that among 1065 couples participating in the study, 747 (70.1\%) had no sick child, while 318 (29.9\%) had given birth to at least one sick child as a result of the current or previous pregnancies.

After descriptive analyses and initial statistical comparisons, a binary logistic regression model was constructed and analysed to define affecting factors of having a sick child. The dependent variable was "having a sick child" and the independent variables were "age (for each gender)", "marriage before 1994 (legal obligation start year for prenatal testing in Turkey)", "educational status (6 categories for each gender)", "family willingness for screening (in none of the families, in either one of the families, i.e. in either the family of the bride or in that of the groom, or in both of the families)", "age at marriage", "economic income (as low, middle, high)", "kinship (as first, second degree, none)", "social security presence". The significant risk factors $(p<0.05)$ for having a sick child were found to be age, which increased the risk by 1.060 times for each age increase in years with $95 \%$ confidence interval $(95 \% \mathrm{Cl})$ between 1.002 and 1.122; being married before 1994 increased the risk by 2.121 times (95\% $\mathrm{Cl}=1.081-4.161)$, family screening decreased the risk by 0.378 times $(95 \% \mathrm{Cl}=0.167-0.854)$, partus frequency had no

Table 1. The follow-up process pregnant women in the study population

\begin{tabular}{|c|c|c|c|c|c|c|}
\hline \multirow{9}{*}{$\begin{array}{c}144 \text { pregnant } \\
\text { women }\end{array}$} & \multicolumn{5}{|c|}{$\begin{array}{l}25 \text { Excluded from prenatal testing } \\
\qquad= \\
3 \text { ( } \alpha \text {-thalassaemic) } \checkmark \\
4 \text { (spontaneous abortus) } \checkmark \\
18 \text { (pregnancy }>=16 \text { weeks) } \rightarrow\end{array}$} & $\begin{array}{c}\rightarrow \text { Post-partum } \\
\text { Hb electrophoresis } \\
\qquad= \\
2 \text { healthy children born } \\
11 \text { carrier children born }\end{array}$ \\
\hline & \multirow{5}{*}{$\begin{array}{l}119 \text { prenatal } \\
\text { test done }\end{array}$} & \multirow{5}{*}{$\rightarrow$} & & & & 5 sick children born \\
\hline & & & 27 healthy & $\rightarrow$ & $\rightarrow$ birth $\rightarrow$ & 27 healthy children born \\
\hline & & & 73 carrier & $\rightarrow$ & $\rightarrow$ birth $\rightarrow$ & 73 carrier children born \\
\hline & & & \multirow[t]{2}{*}{19 sick } & 17 accepted medical abortus & $X$ & 17 sick children prevented \\
\hline & & & & 2 denied medical abortus & $\rightarrow$ birth $\rightarrow$ & 2 sick children born \\
\hline & \multirow{3}{*}{$\begin{array}{c}18 \text { prenatal test } \\
\text { not done }\end{array}$} & \multirow{3}{*}{$\rightarrow$} & \multirow{3}{*}{$\rightarrow$} & \multirow{3}{*}{$\rightarrow$} & \multirow{3}{*}{$\rightarrow$ birth $\rightarrow$} & 2 healthy children born \\
\hline & & & & & & 11 carrier children born \\
\hline & & & & & & 5 sick children born \\
\hline
\end{tabular}


Table 2. Final regression model for risk factors to have a sick child

\begin{tabular}{|lccccc|}
\hline & \multicolumn{5}{c|}{ Statistics } \\
\cline { 2 - 6 } Risk Factors & B & Sig. & Exp(B) & Lower & Upper \\
\hline Age* & 0.058 & $0.043^{*}$ & 1.060 & 1.002 & 1.122 \\
Marriage before 1994* & 0.752 & $0.029^{\star}$ & 2.121 & 1.081 & 4.161 \\
Family willingness for screening* & -0.974 & $0.019^{\star}$ & 0.378 & 0.167 & 0.854 \\
Partus frequency & 0.270 & 0.053 & 1.310 & 0.997 & 1.721 \\
Prenatal test frequency rate* & -1.400 & $0.000^{\star}$ & 0.247 & 0.147 & 0.414 \\
Age at first pregnancy* & -0.442 & $0.006^{*}$ & 0.643 & 0.469 & 0.882 \\
Constant & -4.914 & 0.002 & 0.007 & & \\
\hline *Significant factors $(p<0.05)$ & & & & & \\
\hline
\end{tabular}

risk effect, prenatal test frequency rate decreased the risk by 0.247 times $(95 \% \mathrm{Cl}=0.147-0.414)$, and age at first pregnancy decreased the risk by 0.643 times $(95 \% \mathrm{Cl}=0.469-0.882)$. The final model was presented at table 3 (Table 2).

\section{Discussion}

Haemoglobinopathies and thalassaemias, which are important public health problems for both Hatay region and Turkey, are both preventable diseases with incidences up to $13.0 \%(7,25,26)$.

The main or final target of this kind of study is the prevention of all haemoglobinopathic births, in other words, the elimination of the births of sick children. Prevention has been considered superior to treatment worldwide (27). Our approach was consistent with other researchers like Giordano, who affirmed that the key elements to preventing haemoglobinopathies were information, carrier diagnosis and genetic counselling (28). Among the 1065 couples included in our study, $29.9 \%$ were found to have at least one sick child in the family. The follow-up of 144 pregnant carrier women determined during the study, revealed the birth of a total of 12 (8.3\%) sick children and 95 carrier children, while the birth of $17(11.8 \%)$ sick children was prevented.

After a series of descriptive analyses, we constructed a binary logistic regression model to define affecting factors of having a sick child (i.e. the dependent variable), which was the main interest of the study.

Among the independent variables, one of the significant risk factors $(p<0.05)$ for having a sick child was found to be "age" which increased the risk by $1.060(95 \% \mathrm{Cl}=1.002$ and 1.122) times for each yearly increase in age. The educational and economic profile of the study group was not high (reported as middle income level by $75 \%$ ), with $10.0 \%$ not being covered by any social security assistance. The frequency of illiterate women was three times higher than the husbands in the group. This was an indirect effect of age as a risk factor, because the educational status of Turkish women was reported to improve over time (29); in other words older age groups tended to have lower educational status. Voskaridou et al. (27) also reported financial reasons and low educational levels to be the main causes of affected births as between 7\% (among people of Roma origin) and 27\% (among immigrants). This finding was also supported by the fact that the older the woman's age, the earlier the year of marriage was; hence the date of marriage could be prior to 1994. Thus, "being married before 1994", was another risk factor in our study which increased the risk of having a sick child by 2.121 times $(95 \% \mathrm{Cl}=1.081-4.161)$. In the context of the "Haemoglobin Diseases Control Programme", the WHO suggests the education of people, determination of carriers, population screenings, the definition of local mutations, treatment, genetic counselling and prenatal diagnosis to be performed as a whole in a coordinated manner. The fight against haemoglobinopathies in Turkey was officially started by "the law of fight against hereditary blood diseases (no.3960)" printed in the Turkish Official Gazette in December 30, 1993 (no.21804) (30). Followed by the establishment of "Congenital Blood Diseases Research and Treatment Centres" by Turkish Ministry of Health in the provinces of Antakya, Mersin, Muğla and Antalya, the screening test for thalassaemia was declared compulsory for couples planning to marry. In June 23 2000, the "National Haemoglobinopathy Council" was established for screening, registry, education, prenatal diagnosis and conventional screening (4, 17). Kılınç emphasised the usefulness of premarital screening programs in the evaluation of haemoglobinopathies in Turkey (7). The need for similar programs was also reported by Ferreira et al. (3) in the case of Brazil. The effect of these legal obligations was observed in our study with a dramatic increase of pre-marital testing from $5.1 \%$ among couples married before 1994 to $95.0 \%$ among those married after 1994. It is worth emphasising that $98.9 \%$ of the couples declared the legal obligation as the reason for performing the test.

The "prenatal test frequency rate" was calculated by logistic regression analysis as a factor for decreasing the risk of having a sick child by 0.247 times $(95 \% \mathrm{Cl}=0.147-0.414)$. The most frequent reason for not having the test was declared as unawareness of the test (66.0\%), followed by economic insufficiencies (17.1\%), destiny/religious reasons $(9.1 \%)$ and family interference (7.8\%). Some of the women who had the test only in the first pregnancy but not in the following ones, explained this mostly by economic reasons (33.3\%), but some 
$8.8 \%$ had a belief that this disease could be observed only in the first child. Unawareness of prenatal screening tests or lack of knowledge about haemoglobinopathies accounting for the reasons of haemoglobinopathic births, with $0.3 \%$ among couples who had resigned to marrying and $2.0 \%$ among those whose decision to marry was not affected by the results of prenatal testing. Voskaridou et al. (27) reported the risk effect of unawareness as $23 \%$, and that of religious reasons as $13 \%$.

Another factor decreasing the risk of having a sick child by 0.378 times $(95 \% \mathrm{Cl}=0.167-0.854)$ was found to be "family willingness for screening" in our study. Social or bioethical reasons unrelated to religion were declared by parents opposed to prenatal testing in $13 \%$, as reported by Voskaridou et al. (27). The kinship of the first and second grade was found to be $26.3 \%$ and $10.0 \%$ among the couples in our study, respectively. The kinship was reported as an important factor in the frequency of diseases like haemoglobinopathies and thalassaemias. In a study by Asadi-Pooya et al. (31), performed in Iran where age, gender and kinship of patients with thalassaemia major were investigated, it was found that $40.6 \%$ of $\beta$-thalassaemia patients were children born into marriages between first cousins. The difference was found to be statistically significant compared to the normal population. Turkey witnesses a high rate of consanguineous marriages. According to Turkish Population and Health Research repeated every 5 years in a period of nearly 40 years, the rate has been between $20 \%$ and $25 \%$ since 1983 . Among consanguineous marriages, nearly $70 \%$ occur among first cousins (29). The rates found in our study are higher than the country statistics due to the ethnically close characteristic of the population in the region. Consanguineous marriages are also another factor inversely affecting the families' willingness for screening.

Another independent variable of the model, "age at first pregnancy" which decreased the risk by 0.643 times $(95 \% \mathrm{Cl}=0.469-0.882)$ was controversial to the effect of age itself. However, this is, in fact, the effect of more sensitive parents and families for the expected child called also "precious baby", seeking more medical advice, and more experience, as the birth has been retarded in these cases due to different medical or social causes, as also previously confirmed by other studies (27). Loukopoulos reported a similar finding but in a reverse pattern; despite being more informed, the large majority of young people nowadays appear less sensitive, i.e. their fear of bearing an affected child was lower compared to previous years (32). Savas et al. (33) who researched the haemoglobinopathy awareness among high school students in Antakya (Antioch), which is the central district of Hatay Province, similarly reported the importance of enlightenment of the students, particularly adolescents, and the public about this disease, suggesting also the urgent revision of the Haemoglobinopathy Control Programme.

In conclusion, besides all legal regulations and applications, time is still needed for real success against such a diffuse and congenitally transferred disease. The education of the target populations appears to be crucial, but especially at a stage before the couples take the decision to get married, i.e. at school age. On the other hand, easy, cheap and practically applicable treatment methods are needed for patients. Official applications should be forced based upon present or future laws.

Ethics Committee Approval: The program was ethically approved by Hatay Provincial Health Directorate and the ethical committee of Mustafa Kemal University Faculty of Medicine, Hatay, Turkey.

Informed Consent: Informed consent was received from the participants of this study.

Peer-review: Externally peer-reviewed.

Author contributions: Concept-E.N., Ö.Ç., B.K.; Design - E.N., Ö.Ç.; Supervision - E.N., H.D.; Data Collection\&/or Processing - Ö.Ç.; Analysis\&/ or Interpretation - H.D.; Literature Search - E.N., H.D.; Writing -E.N., H.D.; Critical Reviews - E.N., H.D., M.A., M.K.

Conflict of Interest: The authors declare that they have no conflict of interest.

Financial Disclosure: The project was financially supported by Doğaka Development Agency (Doğaka Financial Support Program for Social Development; TR63-10-10-SKA-29).

\section{References}

1. Cavalli-Sforza LL, Menozzi P, Piazza A. The History and Geography of Human Genes. Princeton University Press, New Jersey, 1994.

2. Weatherall DJ, Clegg JB. Inherited haemoglobin disorders: an increasing global health problem. Bull World Health Organ 2001;79:704-12.

3. Ferreira TDS, Freire AS, Silveira-Lacerda EDP, Garcia-Zapata MTA. A model of genetic guidance for hemoglobinopathy patients and laboratory diagnosis of family members as educational and preventive measures. Rev Bras Hematol Hemoter 2012;34:339-44. [CrossRef]

4. WHO. Guidelines for the control of hemoglobin disorders. In: Model B (ed). World Health Organization Hereditary Disease Programme. Document of the VIth annual meeting of WHO working group on hemoglobinopathies, Sardinia, 1989. (WHO/HDP/HB/ GL/94.1); 1994. pp.1-62.

5. Modell B, Kuliev A. The history of community genetics: the contribution of the haemoglobin disorders. Community Genet 1998;1:3-11. [CrossRef]

6. Modell B, Darlison M. Global epidemiology of haemoglobin disorders and derived service indicators. Bull World Health Organ 2008;86:480-7. [CrossRef]

7. Kılınç Y. Hemoglobinopathies in Turkey. Turk J Hematol 2006;23:214-6.

8. Higgs DR. Gene regulation in hematopoiesis: New lessons from thalassemia. Hematology Am Soc Hematol Educ Program 2004;1-13. [CrossRef]

9. Jans $S M$, de Longe $A$, Henneman L, Cornel MC, Lagro-Janssen ALM. Attitudes of general practitioners and midwives towards ethnicity-based haemoglobinopathy-carrier screening. Eur J Hum Genet 2012;20:1112-7. [CrossRef]

10. Kohne E, Kleihauer E. Hemoglobinopathies: a longitudinal study over four decades. Dtsch Arztebl Int 2010;107:65-71.

11. May C, Sadelain M. A promising genetic approach to the treatment of beta-thalassemia. Trends Cardiovasc Med 2001;11:276-80. [CrossRef]

12. Yuregir GT, Donma O, Dikmen N, Ispir T, Çinar M. Population studies of hemoglobin $S$ and other variants in Çukurova, the southern part of Turkey. Nihon Ketsueki Gakkai Zasshi 1987;50:757-65.

13. Canatan D, Kose MR, Ustundag M, Haznedaroglu D, Ozbas S. Hemoglobinopathy Control Program in Turkey. Community Genet 2006;9:124-6. [CrossRef] 
14. Gali E, Polat G, Dogdu O, Akgol M, Parlar M, Yuregir G. Premarital hemoglobinopathy screening in Kocaeli, Turkey: a crowded industrial center on the north coast of Marmara Sea. Journal of Mersin University, Faculty of Medicine 2001;3:305-10.

15. Kilinc $Y$, Kumi M, Gurgey A, Altay C. Determination of the frequency of alfa-thalassemia, G6PD enzyme deficiency and Hb-S in cord blood samples from infants born in Adana region. DOĞA 1986;10:162-7.

16. Guvenc B, Canataroglu A, Unsal C, Yildiz SM, Turhan FT, Bozdogan $S T$, et al. $\beta$-Thalassemia mutations and hemoglobinopathies in Adana, Turkey: results from a single center study. Arch Med Sci 2012;8:411-4. [CrossRef]

17. Angastiniotis $M$, Modell $B$, Englezos $P$, Boulyjenkov V. Prevention and control of haemoglobinopathies. WHO Bulletin OMS 1995;73:375-86.

18. Bandeira FM, Santos MN, Bezerra MA, Gomes YM, Araujo AS, Braga $\mathrm{MC}$, et al. Family screening for $\mathrm{HBB}^{\star} \mathrm{S}$ gene and detection of new cases of sickle cell trait in Northeastern Brazil. Rev Saude Publica 2008;42:234-41. [CrossRef]

19. Cao A, Pirastu M, Rosatelli $C$. The prenatal diagnosis of thalassaemia. Br J Haematol 1986;63:215-20. [CrossRef]

20. Bozkurt $G$. Thalassemia prevention and control program in the Turkish Republic of Northern Cyprus. In: Bozkurt G (ed) 2nd International Thalassemia Summer School, 01-05 April 2002, Girne, KKTC, p. 41.

21. Bozkurt G. Results from the North Cyprus thalassemia prevention program. Hemoglobin 2007;31:257-64. [CrossRef]

22. Balseven A, Ozdemir C, Bilge Y. Problem of determination of thalassemia carriage. Sted 2002;11:378-9.

23. Yücel Ö. Legal aspect of prenatal examination and tests. Adli Bilimler Dergisi 2009;8:37-47.
24. Tunçbilek E, Özgüç M. Application of medical genetics in Turkey Turk J Pediat 2007;49:353-9.

25. Arcasoy A, Canatan D. Thalassemias and haemoglobinopathies in the World and Turkey. The Prevention, Diagnosis and Treatment Book of Thalassemias and Haemoglobinopathies. Turkish Republic, Ministry of Health, Department of Child and Maternal Health and Family Planning. Ankara, 2002;11-7.

26. Aluoch JR, Kilinc Y, Aksoy M, Yuregir GT, Bakioglu I, Kutlar A, et al. Sickle cell anaemia among Eti-Turks: haematological, clinical and genetic observations. Br J Haematol 1986;64:45-55. [CrossRef]

27. Voskaridou E, Ladis V, Kattamis A, Hassapopoulou E, Economou $M$, Kourakli $A$, et al. A national registry of haemoglobinopathies in Greece: Deducted demographics, trends in mortality and affected births. Ann Hematol 2012;91:1451-8. [CrossRef]

28. Giordano PC. Prospective and retrospective primary prevention of hemoglobinopathies in multiethnic societies. Clin Biochem 2009;42:1757-66. [CrossRef]

29. Hacettepe University, Institute of Population Studies. Turkey Demographic and Health Survey 2008. Hacettepe University Hospitals Printing House, Ankara, 2008.

30. Turkish Official Gazette-No:21804 (Print date:30/12/1993). Law of fight against hereditary blood diseases (no.3960 and dated 28/12/1993).

31. Asadi-Pooya AA, Doroudchi M. Thalassemia major and consanguinity in Shiraz city, Iran. Turk J Haematol 2004;21:127-30.

32. Loukopoulos D. Haemoglobinopathies in Greece: prevention programme over the past 35 years. Indian J Med Res 2011;134:572-6.

33. Savas N, Turhan E, Inandi T, Kaya H. Hemoglobinopathy awareness among high school students in Antakya, Turkey. Int J Heamtol 2010;91:413-8. [CrossRef] 